\title{
Analysis of the Factors That Affect the Quality of Life of Patients with Parkinson's Disease in the Clinic of Neurology of the Hospital Royal Prima Medan 2019
}

\author{
M Dwiky Yunarko ${ }^{1}$, Linda Chiuman ${ }^{2}$, Sri Wahyuni Nasution ${ }^{3}$, Ermi Girsang $^{4}$ \\ ${ }^{1}$ Postgraduate Students, Department Magister of Public Health, Faculty of Medicines at University Prima \\ Indonesia \\ ${ }^{2,3,4}$ Postgraduate Lecturer, Department Magister of Public Health, Faculty of Medicines at University Prima \\ Indonesia
}

Corresponding Author: Ermi Girsang [Email: ermigirsang@unprimdn.ac.id]

\begin{abstract}
An estimated 50,000 Americans are diagnosed with Parkinson's disease each year, according to the National Institutes of Health, and around one million Americans have the condition.

To find out the analysis of the factors that influence the quality of life of Parkinson's sufferers at the Neurology Polyclinic at The Royal Prima Hospital in 2019.

There is a relationship between age and quality of life and social relations of patients with Parkinson's in the Neurology Polyclinic of The Royal Prima Hospital in 2019. There is no relationship between gender and stadium of Parkinson's disease with the quality of life of patients with Parkinson's in the Neurology Polyclinic of The Royal Prima Hospital in 2019 in Medan.

It is expected that the Hospital must continue to pay attention and improve in order to create quality and high-quality services at The Royal Prima General Hospital, Medan, especially regarding the factors that affect the quality of life of Parkinson's sufferers.
\end{abstract}

Keywords: Factors Affecting the Quality of Life of Parkinson's Patients

\section{INTRODUCTION}

Parkinson's disease is a disorder of brain function that is pathological is characterized by degeneration of nerve cells in the brain called the basal ganglia, the loss of pigmentation in the substantia nigra, the inclusion cytoplasmic called Lewy bodies, as well as a decrease of dopamine in the substantia nigra pars kompakta (SNC) and the corpus striatum.1 Parkinson's Disease usually appear at the age of 40-70, the average above 55 years of age and is rare under the age of 30 years or after the age of 80 years (Tarukbua. 2016)

Parkinson's, a degenerative disease that attacks the brain is still a scourge for the people of the world, including Indonesia. The number of patients with disease that primarily affects the elderly aged 65 years and above is expected to increase by touching the numbers of 6.17 million people in 2030 (Manafe. 2015).

An estimated 50,000 Americans are diagnosed with Parkinson's disease each year, according to the National Institutes of Health, and about one million Americans have the condition (Pharmaceutical, 2016).

While in Indonesia, as quoted from the site penyakitparkinson.com, 40-50 visits each month in Cipto Mangunkusumo Hospital, Jakarta is the Parkinson's patients and 3 of them are of Parkinson's disease with a new case. Neurological disorder usually occurs in people over the age of 60 , when the cells in the brain that produce a chemical called dopamine become disabled or die (Pharmaceutical, 2016). 
The number of patients with Parkinson's disease in Indonesia is expected to increase to 75 thousand every year. Even in the entire world, the number of patients with Parkinson's reached more than 4 million people per year (Amaluddin, 2015).

From the initial survey that the researchers did in the Hospital The Royal Prima Medan in January 2019 there were 389 patients in poly nerve Hospital Royal Prima Medan with age above 40 years.

\section{LITERATURE REVIEW Parkinson's}

Parkinson's disease or Parkinson's disease (PD) is of neurodegenerative disorders that are progressive are about the movement or control of the movement, including talk and have an onset is insidious (Gunawan. 2017).

Age

According to Notoadmodjo 2012, age is a variable that is always considered in the investigation -the investigation of the epidemiology. The numbers of pain and death in almost all circumstances show relationship with age.

\section{Gender}

Gender is the distinction of the role, status, responsibility, and the division of labor between men and women established by the society based on the nature of the women and men that are considered inappropriate according to the norms, customs, beliefs or habits of society (BPS, 2016).

\section{Stage Parkinson's Disease}

According to Ryanto 2013, the Criteria for diagnosis of Parkinson's disease in general is to find 2 of the 3 cardinal signs of motor impairment, i.e., tremor, rigidity, and bradykinesia, or three of the four the sign of the motor, i.e. the third sign of the above plus the instability postural.

\section{Social Activity}

According to Anindyaputri 2017, physical activity is the activities in a specific duration of time, which requires energy and movement of the muscles of the skeleton.

\section{Quality Of Life}

According to WHO (2004) Quality of life is the perception of the individual in his review of konsteks culture, behavior and value system where they live and relate to living standards, hopes, pleasures, and the assessment of individuals to their position in life (Lara, 2013).

\section{Independent Variable}

\section{Dependent Variable}
1. Age
2. Gender
3. Stage Parkinson's Disease
4. Social Relations

\section{The Quality Of Life of \\ Parkinson's Patients}

Figure 1 Conceptual Framework

\section{Hypothesis}

Based on the background research and the relationship between variables, the hypothesis of this research is as follows:

a. Ha: There is relationship of age on the quality of life of patients with Parkinson's disease in the clinic of neurology of the Hospital The Royal prima Medan 2019.

Ho: There is No relationship of age on the quality of life of patients with Parkinson's disease in the clinic of neurology of the Hospital The Royal prima Medan 2019. 
b. Ha: There is a relationship of Gender on quality of life of patients with Parkinson's disease in the clinic of neurology of the Hospital The Royal prima medan 2019.

Ho: There is No relationship of Gender on quality of life of patients with parkinson's disease in the clinic of neurology of the Hospital The Royal prima medan 2019.

c. Ha: There is a relationship stage parkinson's disease on quality of life of patients with parkinson's disease in the clinic of neurology of the Hospital The Royal prima medan 2019.

Ho: There is No relationship stage parkinson's disease on quality of life of patients with parkinson's disease in the clinic of neurology of the Hospital The Royal prima medan 2019.

d. Ha: There is a relationship of social activity on quality of life of patients with parkinson's disease in the clinic of neurology of the Hospital The Royal prima medan 2019.

Ho: No relationship of social activity on quality of life of patients with parkinson's disease in the clinic of neurology of the Hospital The Royal prima medan 2019.

\section{MATERIAL AND METHODS}

Researchers used a quantitative approach with the method of survey, with emphasis on hypothesis testing. In this approach, the data obtained in various ways, among others by observation, the division of the questionnaire/ questionnaires, or interviews, with the intention of getting the data that can be analyzed accurately and results the conclusion can be generalized. This research was conducted in a Hospital Royal Prima Medan in March 2019.

The population is defined as a generalization region consisting of: object/subject that has the qualities and characteristics determined by the researchers to be studied and then drawn conclusions (Sugiyono, 2013). The population in this research is all parkinson's patients in the Poly Clinic Nerves Hospital Royal Prima Medan as many as 52 people. The samples in this study were as many as 52 people.

Types And Sources of Data this Study obtained data from several sources, among others: primary Data is data obtained from the related parties of the division of the questionnaire, namely competence, and leadership style training. Secondary Data is the primary data have been further processed and presented by both the primary data collector or by the other party. Secondary Data can be in the form of notes, documents or historical reports (archive) published and unpublished.

Techniques used in data collection are: Observation; namely the collection of data by conducting direct observations of things that are considered necessary and related to the object of research. Direct interview; namely the collection of data by direct questioning and Questionnaires / Questionnaires; that respondents from partyparty agencies related to the problems studied.

\section{RESULTS AND DISCUSSION Analysis Of Age On The Quality Of Life Of Patients With Parkinson's}

Statistics show that the value of $3,989 \mathrm{df}=1$ with a value of 0.05 significance where the calculated X2 > X2 table means that $\mathrm{Ha}$ is accepted and $\mathrm{Ho}$ is rejected, meaning that there is a relationship between age and quality of life.

According to the assumptions of researchers at the Hospital The Royal Prima Medan there is a high frequency of parkinson's disease at the age of $>40$ years compared to age < 40years. It is related to the reaction mikrogilial that affect the damage of neuronal, especially in the substantia nigra in parkinson's disease.

According to research Tarukbua 2016 Picture of the cognitive function of patients with parkinson's disease in the Clinic of Nervous RSUP Prof. Dr. R. D. Kandou Manado, the obtained results the Results of research to get 31 Parkinson's 
patients hose months of NovemberDecember 2015. There were 27 patients with a decrease in cognitive function, most often found in male gender, the age group of 61-70 years, education level high School/equivalent, and who are not working including the men retired.

\section{Analysis Of Gender On Quality Of Life Of Patients With Parkinson's}

Statistics show that the value of the $0,929 \mathrm{df}=1$ with a value of 0.05 significance where the calculated X2 $<\mathrm{X} 2$ table means that $\mathrm{Ho}$ is rejected and $\mathrm{Ha}$ accepted, meaning that there is no relationship between gender and quality of life.

According to the assumptions of researchers at the Hospital The Royal Prima Medan there are gender sufferers of Parkinson's is more male than in the female, in this case there is no gender relations and quality of life of patients with Parkinson's disease.

According to the study Below 2018 about the Depiction of Sexual Dysfunction, Disability and Quality of Life in Post-Stroke Patients in the Outpatient Poly Neurology General Hospital Center Haji Adam Malik Medan obtained results: We identified 45 patients with post-stroke. The average age of $60.27+10.12$ years. The majority of $93.3 \%$ of reported experiencing sexual dysfunction. Most of the research subject does not have symptoms of the disability $(64.4 \%)$ and did not have the full dependence $(55.5 \%)$. Quality of life is relatively better in men and especially in the physical domain. Conclusion: the Majority of post-stroke patients experience sexual dysfunction. Quality of life is relatively worse in men and the average disabilities of the most widely is no symptoms of the disability and independent category.

\section{The Analysis Stage Of Parkinson's Disease On Quality Of Life Of Patients With Parkinson's}

Statistics show that the value of $2,440 \mathrm{df}=4$ with a value of 0.05 significance where the calculated $\mathrm{X} 2<\mathrm{X} 2$ table means that $\mathrm{Ho}$ is rejected and $\mathrm{Ha}$ accepted, meaning that there is no relationship between stage of parkinson's disease with quality of life.

According to the assumptions of researchers at the Hospital The Royal Prima Medan there are stadium patients with Parkinson's disease is at stage two, in this case there is no relationship stage Parkinson's disease and quality of life of patients with Parkinson's disease.

According to research Silitonga 2007 about The Factors Associated With Quality of Life of Patients with Parkinson's Disease In the Clinic of Nervous RS DR Kariadi, the obtained results of the 31 patients in the study. There is a significant difference the mean score of the PDQ-39 (p $<0.05)$ of the variable incidence of depression, social activity and the stage of the disease. Conclusion: There is a relationship between the stage of disease, the incidence of depression and social activity and quality of life.

The Analysis Of Social Relations To The Quality Of Life of Patients With Parkinson's Disease In The Clinic Of Neurology Of The Hospital The Royal Prima Medan 2019

Statistics show that the value of $25,812 \mathrm{df}=1$ with a value of 0.05 significance where the calculated X2 > X2 table means that $\mathrm{Ha}$ is accepted and $\mathrm{Ho}$ is rejected, meaning that there is a relationship between the social relations of parkinson's patients with quality of life.

Based on the assumption this researcher found that patients with parkinson's may experience changes in various aspects of life that will affect the physical health, psychological wellbeing, social relationships and environment. This will have an impact on the quality of life of parkinson's patients.

Based on the research Fadlulloh 2014 about the Relationship of the Level of Dependence In the Fulfillment of the Activity of Daily Life (AKS) With the Self- 
esteem of Stroke Patients In the Clinic of Nervous Rsud Prof. Dr. Margono Soekarjo Purwokerto, obtained the results of the analysis obtained $\mathrm{p}$-value $=0.003$ level of correlation $(r)=0,521$. There is a meaningful relationship between the level of dependence in the fulfillment of the activity of daily life (AKS) with the self-esteem of patients with stroke.

Based on the research Juniastira 2018 about the Relationship Between Social Support And Quality of Life In Stroke Patients obtained results of data analysis using Pearson's product moment shows that the correlation between social support and quality of life has a value of $\mathrm{p}=0.000$ ( $\mathrm{p}<$ 0.05 ) with a value of $r=0.938$.

\section{CONCLUSIONS AND RECOMMENDATIONS Conclusion}

Based on the results of research on the Analysis of Factors That Affect the Quality of Life of Patients with Parkinson's disease In the Clinic of Neurology of the Hospital The Royal Prima Medan 2019, then it is taken to the following conclusion:

1. There is a relationship between age and quality of life of Patients with Parkinson's disease In the Clinic of Neurology of the Hospital The Royal Prima Medan 2019.

2. There is no relationship between gender and quality of life of Patients with Parkinson's disease In the Clinic of Neurology of the Hospital The Royal Prima Medan 2019.

3. There is no relationship between stage of parkinson's disease and quality of life of Patients with Parkinson's disease In the Clinic of Neurology of the Hospital The Royal Prima Medan 2019.

4. There is a relationship between the social relations of parkinson's patients with quality of life. Patients With Parkinson's Disease In The Clinic Of Neurology Of The Hospital The Royal Prima Medan 2019.

\section{Recommendations}

Suggestions researchers from the research that has been done about the "Analysis of the Factors That Affect the Quality of Life of Patients with Parkinson's disease In the Clinic of Neurology of the Hospital The Royal Prima Medan 2019" is as follows:

\section{For The Hospital}

It is expected that the Hospital must still pay attention and improve it for the creation of quality services and highquality in the General Hospital Royal Prima Medan, especially about the Factors That Affect the Quality of Life of Patients with Parkinson's disease In the Clinic of Neurology of the Hospital The Royal Prima Medan 2019

\section{For further research}

Further research is expected to examine more sources and references related to the Analysis of the Factors That Affect the Quality of Life of Patients with Parkinson's disease In the Clinic of Neurology of the Hospital The Royal Prima Medan 2019 so that research results can be better and more complete.

\section{Acknowledgement: None}

\section{Conflict of Interest: None}

\section{Source of Funding: None}

Ethical Approval: Approved

\section{REFERENCES}

1. Anindyaputri, 2017. Berapa Banyak Aktivitas Fisik yang Dibutuhkan Orang Dewasa.https://hellosehat.com/hidup sehat/kebugaran/minimal aktivitas-fisikbagi-orang-dewasa, Diakses tanggal 20 januari 2019.

2. Amaluddin, 2015. Penderita Parkinson di Indonesia Bertambah 75 Ribu perTahun.https://www.medcom.id/rona/kese hatan/gNQLaVVK-penderita-parkinson-diindonesia-bertambah-75-ribu-per-tahun, Diakses tanggal 20 januari 2019.

3. BPS, 2016. Gender. https://www.bps.go.id/. Diakses tanggal 19 Januari 2019. 
4. Farmasetika, 2016. NUPLAZID, Obat Pertama di Dunia Untuk Halusinasi dan Delusi Parkinson, http://farmasetika.com/2016/05/01/nuplazid -obat-pertama-di-dunia-untuk-halusinasidan-delusi-parkinson/. Diakses tanggal 20 januari 2019.

5. Gunawan, 2017. Parkinson Dan Terapi Stem Sel. Fakultas Kedokteran Universitas Brawijaya, Malang, Indonesia.

6. Kemenkes, 2018. Manfaat Aktivitas Fisik http://www.p2ptm.kemkes.go.id/infographic -p2ptm/hipertensi-penyakit-jantung-danpembuluh-darah/manfaat-aktivitas-fisik. Diakses tanggal 20 januari 2019.

7. Lara, 2016. Hubungan Pendidikan, Kebiasaan Olahraga, Dan Pola Makan Dengan Kualitas Hidup Lansia Di Puskesmas Wonokromo Surabaya.

8. Manafe, 2015. 2030, Secara Global Penderita Parkinson Capai 6,17 Juta Orang

9. https:// www. Berita satu. com/kesra 1305743-2030- secara- global-penderita parkinson - capai- 617- juta- orang. html. Diakses tanggal 19 januari 2019.

10. Pratama, 2014.Penyakit Parkinson.https://lovelearnandshare.wordpre ss.com/2014/11/05/penyakit-parkinson/, Diakses tanggal 20 januari 2019.

11. Ryanto, 2013. Penyakit Parkinson. https://www.medicinesia.com/kedokterandasar/neurosains/penyakitparkinson/. Diakses tanggal 20 januari 2019.

12. Silitonga, 2007. Faktor-Faktor Yang Berhubungan Dengan Kualitas Hidup Penderita Penyakit Parkinson Di Poliklinik Saraf RS DR Kariadi. Tesis. Universitas Diponegoro Semarang.

13. Siti, 2016. Kontekstualisasi Gender, Islam Dan Budaya. Samata. Kemitraan Universitas Masyarakat (KUM) UIN Alauddin Makassar.
14. Sudira, 2015.Stroke Lacunar Infarct Pada Pasien Parkinson. Fakultas Kedokteran Universitas Gadjah Mada Yogyakarta

15. Tarukbua, 2016. Gambaran Fungsi Kognitif Penderita Parkinson Di Poliklinik Saraf RSUP Prof.Dr. R.D. Kandou Manado, Fakultas Kedokteran Universitas Sam Ratulangi Manado, Jurnal e-Clinic $(\mathrm{eCl})$

16. UNPRI, 2018. Buku Panduan Proposal Dan Tesis Magister Kesehatan Masyarakat. Medan .

17. Hasanul, 2018. Gambaran Disfungsi Seksual, Disabilitas dan Kualitas Hidup pada Pasien Pasca Stroke di Rawat Jalan Poli Neurologi Rumah Sakit Umum Pusat Haji Adam Malik Medan.Tesis .Universitas Sumatera Utara.

18. Fadlulloh, 2014. Hubungan Tingkat Ketergantungan Dalam Pemenuhan Aktivitas Kehidupan Sehari-Hari (AKS) Dengan Harga Diri Penderita Stroke Di Poliklinik Syaraf Rsud Prof. Dr. Margono Soekarjo Purwokerto. JurnaL Keperawatan Soedirman, Universitas Jendral Sudirman.

19. Juniastira, 2018. Hubungan Antara Dukungan Sosial Dan Kualitas Hidup Pada Pasien Stroke.Skripsi. Universitas Islam Indonesia Yoyakarta.

20. Tarukbua, 2016. Gambaran fungsi kognitif penderita parkinson di Poliklinik Saraf RSUP Prof. Dr. R. D. Kandou Manado, Jurnal- Eclinik Universitas Sam Ratulangi Manado.

How to cite this article: M Dwiky Yunarko, Chiuman L, Nasution SW et.al. Analysis of the factors that affect the quality of life of patients with parkinson's disease in the clinic of neurology of the Hospital Royal Prima Medan 2019. International Journal of Research and Review. 2021; 8(8): 176-181. DOI: https://doi. org/10.52403/ijrr.20210824 